\title{
Fenomena Klasik Pada Tinggalan Arkeologis Dari Masa Kerajaan Demak Di Desa Prawoto
}

\section{Libra Hari Inagurasi}

Keywords: demak, palace, character, description, hindu, islam

\section{How to Cite:}

Inagurasi, L. H. (2001). Fenomena Klasik Pada Tinggalan Arkeologis Dari Masa Kerajaan Demak Di Desa Prawoto. Berkala Arkeologi, 21(2), 56-67. https://doi.org/10.30883/jba.v21i2.841

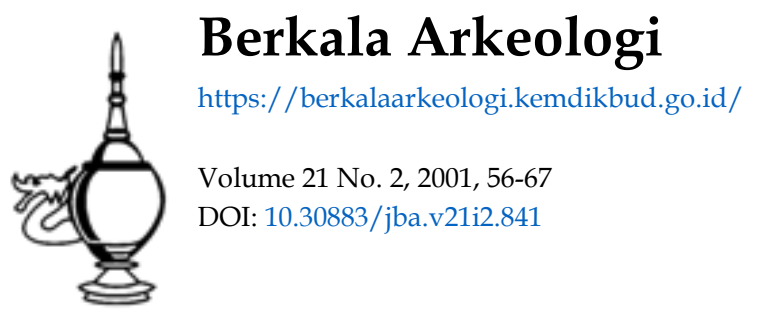

\section{c) (i) (2)}

This work is licensed under a Creative Commons Attribution-NonCommercial-ShareAlike 4.0 International License. 


\title{
FENOMENA KLASIK PADA TINGGALAN ARKEOLOGIS DARI MASA KERAJAAN DEMAK DI DESA PRAWOTO
}

\author{
Libra Hari Inagurasi \\ (Pusat Penelitian Arkeologi)
}

\section{Pendahuluan}

Prawoto merupakan sebuah desa yang secara administratif termasuk Kecamatan Sukolilo, Kabupaten Pati, Propinsi Jawa Tengah. Desa Prawoto mencakup 6 dukuh yaitu: Sewunegaran, Karangtandan, Perangan, Sawahan, Domasan, dan Plosokerep. Bagian Utara desa dibatasi oleh Desa Kutuk, Kabupaten Kudus; bagian selatan oleh Desa Klambu, Kabupaten Grobogan; bagian Barat oleh Desa Lambangan, Kabupaten Kudus; dan bagian Timur oleh Desa Pakem dan Wugil, Kabupaten Kudus. Dibandingkan dengan wilayah di sekitarnya letak Desa Prawoto lebih tinggi karena berada di sebuah bukit. Di bagian bawah bukit mengalir saluran irigasi Jrantunseluna yang mencakup aliran Sungai Jragan, Tuntang, Serang, Lusi, dan Juana, karena berada di perbukitan maka desa tersebut banyak dialiri mata air yang dinamakan sendang. sedikitnya terdapat 5 buah sendang yaitu: Jibing,Widodaren, Prianggodo, Soka, dan Garuda.

Penelitian arkeologis di Prawoto pernah dilakukan oleh J.F.G. Brumund pada tahun 1868. Pada masa itu Prawoto yang disebut dengan Parwoto atau Perwata termasuk wilayah Kawedanan Oendakan, Kabupaten Kudus (VBG Deel XLVII Tahun 1891: 103). Di sana Brumund melihat masih ada tinggalan dari masa Hindu, yaitu pintu gerbang yang dinamakan gapoera, yang masih terlihat hanya satu sisi saja dan masih berdiri tegak lurus, berada di tepi bukit yang terjal; lingkungan sekitar gapura ditumbuhi pohon cemara atau pohon pinus. Di belakang pintu gerbang, terdapat yoni setinggi 2 kaki, sepetak tanah kecil yang tinggi, oleh penduduk dipandang sebagai sitinggil keraton ( VBG Deel XXXIII Tahun 1868: 164--165). Di Sendang Garuda yang tidak jauh dari sitinggil, Brumund juga menemukan tempat mandi yang di huni oleh kura-kura yang keramat. Pada masa itu penduduk disana masih menyebut sisa tembok melingkar yang ditemukan di Prawoto sebagai kraton (Graaf, 1985: 23--24).

Berdasarkan beberapa tinggalan arkeologis tersebut, maka Bidang Arkeologi Islam, dari Pusat Arkeologi, pada bulan Juli tahun 2000, telah mengadakan kegiatan survei di situs Prawoto. Dari survei itu diketahui bahwa potensi kepurbakalaan di sana cukup beragam, atau dapat dikatakan sebagai situs multi budaya yang terdiri dari tinggalan pengaruh budaya Hindu, dan pengaruh Islam, serta tinggalan lainnya yang tidak dapat di identifikasi. Meskipun Desa Prawoto cukup luas yaitu I.174 hektar, tetapi persebaran tinggalan arkeologi tidak merata di seluruh wilayah. Potensi arkeologi 
sebagian besar terpusat di Dukuh Sewunegaran, dan sebagian kecil lainnya tersebar di Dukuh Domasan.

Menyimak riwayat penelitian serta keberadaan situs Prawoto seperti tersebut di atas maka permasalahan yang mengemuka kemudian adalah, fenomena klasik seperti apa yang di maksud; dan berfungsi sebagai apakah situs Prawoto itu pada masa lalu.

Mengingat data arkeologis yang ada sebagian besar kondisinya sulit di identifikasi karena berupa tinggalan lepas yang tidak diketahui konteksnya, maka upaya untuk mendapatkan jawaban atas permasalahan ialah, data arkeologis yang di peroleh dikaitkan dengan data tertulis berupa kronik Jawa, cerita rakyat atau legenda, yang berfungsi sebagai data pembanding. Nama (Bukit) Prawoto sangat dikenal oleh masyarakat di daerah Pati dan sekitarnya, lagi pula nama itu dianggap memiliki kaitan dengan nama pesanggrahan Sultan Demak di Bukit Prawoto yang muncul di dalam Babad Demak (Gina dan Dirgosabariyanto, 1981:22).

\section{Tinggalan Arkeologis di Desa Prawoto}

Tinggalan arkeologis di Desa Prawoto selain jumlahnya banyak jenisnya pun beragam. Sayangnya tinggalan itu banyak yang tidak dapat diidentifikasi ataupun tidak diketahui konteksnya. Adapun tinggalan yang masih dapat diidentifikasi sebagai berikut:

\section{a. Batu lesung}

Terbuat dari batu andesit; berbentuk tegak lurus membujur arah utara dan selatan tepat di sebelah utara yoni; panjang mencapai $5 \mathrm{~m} .20 \mathrm{~cm}$; ; pada ujung sebelah selatan bagian permukaannya terdapat lubang bulat bergaris tengah $8,5 \mathrm{~cm}$. Batu tersebut oleh penduduk sekitar disebut dengan watu (batu) lesung. Batu lesung merupakan istilah yang diberikan pada benda batu dari masa prasejarah yang mempunyai lubang atau rongga yang berfungsi sebagai tempat untuk menumbuk biji-bijian. Namun melihat konteks lingkungan yang ada di lokasi, batu lesung itu berada di sebelah yoni, oleh karena itu batu itu sangat diragukan untuk dimasukkan ke dalam periode prasejarah. Mungkin batu lesung itu telah digunakan untuk keperluan atau fungsi lainnya lebih dari sekedar alat atau tempat untuk menumbuk biji-bijian.

\section{b. Yoni}

Terbuat dari bahan batu andesit; berdenah segi empat, tinggi $72,5 \mathrm{~cm}$. , panjang masing-masing sisi pada bagian permukaan $90 \mathrm{~cm}$., dengan kedalaman lubang yoni 42 $\mathrm{cm}$. Melihat bentuknya yoni tersebut jelas menampakkan yoni tinggalan dari masa 
Hindu yang berpasangan dengan lingga. Yoni merupakan media untuk melakukan ibadah selain candi, bagi umat Hindu. Dalam melakukan ibadah, umat Hindu tidak harus berada di dekat atau di dalam sebuah candi. Artefak lingga-yoni dapat pula menjadi sasaran pemujaan.

Lingga adalah perwujudan Dewa Siwa di dunia, adapun yoni adalah perwujudan Dewa Bumi sekaligus istri Siwa. Pertemuan lingga dan yoni merupakan proses penciptaan manusia di dunia. Lingga dan yoni selalu diletakkan di suatu tempat yang lebih tinggi dari pada permukaan tanah tempat orang-orang berdiri atau berjalan. Hal demikian sebagai tanda bahwa lingga dan yoni berada lebih tinggi dari posisi manusia, karena lingga-yoni dipuja oleh Umat Hindu.

Walaupun demikian, karena yoni di Prawoto adalah tinggalan lepas tidak memiliki karakter khusus untuk mengetahui periodisasinya, serta tanpa disertai tinggalan lainnya yang mendukung bukti aktivitas religius umat Hindu (baik candi atau arca), maka hanya dengan artefak yoni saja, sulit untuk dikatakan bahwa dahulu di Prawoto telah berlangsung kegiatan pemujaan oleh umat Hindu.

\section{c. Batu silinder}

Dari bahan batu silikat, membujur arah utara selatan, berukuran panjang $65 \mathrm{~cm}$., lingkar besar $74 \mathrm{~cm}$., lingkar kecil $69 \mathrm{~cm}$.

\section{d. Lapik arca}

Beberapa lapik arca terbuat dari batu andesit; kondisinya ada yang masih utuh dan ada pula yang telah rusak pada bagian tepian atau permukaannya. Berdenah segi empat sama sisi, masing-masing sisi permukaan berukuran $50 \mathrm{~cm}$., tinggi $38 \mathrm{~cm}$, pada bagian permukaannya terdapat lubang segi empat berdiameter $27 \mathrm{~cm}$. Lapik arca di sebut pula dengan pedestral atau asana yang berfungsi sebagai tempat duduk atau berdirinya arca. Tinggalan lapik arca di Prawoto tersebut tidak disertai dengan temuan arca, yang menjadi pasangannya.

\section{e. Umpak batu}

Beberapa umpak batu terbuat dari batu andesit, berdenah segi empat dengan ukuran besar kecilnya bervariasi antara $25-50 \mathrm{~cm}$. Karena umpak menjadi alas tempat berdirinya tiang dari suatu bangunan, maka tentunya berfungsi konstruktif (penyangga bangunan). 


\section{f. Runtuhan bangunan}

Runtuhan bangunan berukuran luas $8 \times 5 \mathrm{~m}$. dan tinggi $130 \mathrm{~cm}$., berada di sebelah timur laut lokasi yoni. Dari sisa-sisa bangunan yang masih dapat di amati, runtuhan bangunan tersebut terbuat dari bahan batu bata (bata merah).

\section{g. Tumpukan bata}

Sebuah tumpukan batu putih (batu padas), ada yang berpahat (pahatan teknis), berpelipit, dan polos berada di bawah pohon, ketinggian tumpukan $189 \mathrm{~cm}$. Terletak + $150 \mathrm{~m}$. di sebelah barat laut dari lokasi yoni, dan dikenal sebagai gapura. Tumpukan batu putih itu sudah tidak menampakkan sebagai bangunan gapura dan sudah tidak insitu. Menyimak laporan dari Brumund, bahwa dia pada akhir tahun 1800 masih melihat satu sisi bangunan gapura, diperkirakan gapura itu berbentuk candi bentar yakni gapura yang tidak beratap. Pada saat sekarang gapura itu sudah tidak ada, mungkin telah dipindahkan oleh penduduk sebagai tumpukan bata yang dimaksud tersebut

\section{h. Makam (petilasan) Sunan Prawoto dan istri}

Makam Sunan Prawoto dan istrinya berada di sebelah timur lokasi yoni. Bercungkup, nisan dan jirat terbuat semen dan keramik sehingga tidak memperlihatkan ciri-ciri kekunaan. Disebut dengan petilasan karena sebenarnya tidak ada yang dimakamkan, Makam Sunan Prawoto sendiri berada di Demak. Walaupun demikian petilasan tersebut memberikan informasi mengenai adanya tokoh sejarah yang pernah tinggal di sana, sekaligus sebagai simbol penghargaan terhadap tokoh sejarah.

Selain makam (petilasan) itu, terdapat pula makam kuna yang lain. Di dukuh Domasan terdapat makam yang masih terlihat ke kunaannya, penduduk menyebut dengan makam Mbah Amir. Bentuk nisannya ada kemiripan dengan nisan tipe Demak yang berbentuk kurung kurawal; berukuran panjang $25 \mathrm{~cm}$. lebar bagian atas $15 \mathrm{~cm}$. dan tebalnya $5 \mathrm{~cm}$., kondisinya tidak terawat. Oleh karena itu membedakannya dengan bentuk nisan dari makam yang baru (berasal dari periode kemudian). Siapakah tokoh Amir, informasi yang diperoleh dari penduduk sekitar menyebutkan, dia adalah salah seorang pengikut Sunan Prawoto.

\section{i. Masjid Jami Kauman}

Berada di Dukuh Sewunegaran, namun lokasinya berbeda dengan tinggalan lainnya (yoni, lapik arca, batu lesung, dsb). Jika konsentrasi tinggalan selain masjid tersebut berada di bagian atas perbukitan, maka masjid itu jauh berada di bagian bawah bukit. 
Masjid itu berdenah segi empat, beratap tumpang susun tiga, yang mengingatkan kepada tipe masjid Demak.

\section{Konteks Sejarah}

Tinggalan arkeologis di Desa Prawoto seperti diuraikan tersebut di atas tidak ada indikator pertanggalan atau periodisasi yang dapat dipercaya. Namun demikian petilasan, makam kuna, dan Masjid Jami Kauman memberikan indikasi serta informasi terdapatnya pengaruh dari masa Kerajaan Demak. Karena itulah sebagai pembanding data arkeologis dipergunakan pula sumber-sumber tertulis (yang tertua umurnya) berupa Kronik Jawa, seperti Babad Demak dan Babad Tanah Jawi, ( selama ini penulis belum menemukan sumber tertulis lain yang lebih tua umurnya). Kronik semacam itu nilai informasinya tidak kalah penting dengan tinggalan arkeologis, khususnya informasi tentang Bukit Prawoto di masa lampau. Kendati diselubungi dengan legenda, babad masih layak di pakai karena memberikan gambaran budaya pada masanya, disamping itu di dalamnya terdapat peristiwa kesejarahan yang dapat dijadikan acuan, dan yang lebih penting lagi isi ceritanya dapat dibuktikan dari segi arkeologis atau tinggalan kepurbakalaan.

Nama Prawoto mengacu kepada dua pengertian. Pertama sebagai nama tempat, kedua nama Prawoto sebagai nama tokoh sejarah. Prawoto sebagai nama tempat yang dimaksud yakni sebuah gunung atau bukit yang diyakini menjadi tempat Sultan Demak untuk bersuka ria pada waktu musim hujan. Di Gunung Prawoto ini pula Mangunjaya dan Raden Rangga, Adipati Pati, melarikan diri ketika kalah perang melawan Panembahan Senopati, Raja Mataram (VBG. Deel LI, 1900: 60). Nama Prawoto yang muncul di dalam Babad Demak, ialah terdapatnya pesanggrahan Sultan Demak yang berada di Gunung Prawoto, yang dirusak oleh seekor banteng yang mengamuk. Banteng dapat dikalahkan oleh Ki Jaka Tingkir, sehingga dia dianugerahi putri bungsu Sultan Trenggono (Gina dan Dirgosabariyanto, 1981:22).

Pesanggrahan berasal dari bahasa Jawa mesanggrah yang berarti berdiam atau bertempat tinggal. Dengan demikian pesanggrahan adalah tempat untuk bertempat tinggal. Babad Demak tersebut telah memberikan informasi bahwa raja-raja pada masa dahulu telah mempunyai tradisi berdiam untuk beristirahat di luar tempat tinggalnya di istana kerajaan. Tempat yang di pilih untuk membangun pesanggrahan adalah tempat yang tenang, jauh dari istana atau pusat kerajaan. Selama berada di pesanggrahan, raja tidak melakukan tugas pemerintahan, melainkan beristirahat ataupun berekreasi.Pada masa sekarang, bangunan pesanggrahan itu dapat disejajarkan dengan villa atau rumah peristirahatan. 
Latar belakang atau alasan Sultan Trenggana memilih tempat Bukit Prawoto sebagai pesanggrahan tidak terlepas dari kondisi lingkungan geografis pusat kerajaan atau Ibukota Demak, yang berada di dataran rendah yang tergenang air apabila musim hujan. Selain tidak terkena bahaya banjir Bukit (Gunung) Prawoto juga memiliki panorama alam yang indah, maka sesuai untuk tempat peristirahatan.

Prawoto sebagai nama tokoh sejarah, ia adalah Pangeran Prawoto, anak dari Sultan Demak, Trenggana, yang diangkat menjadi amengkunegoro atau adipatianom (putra mahkota ?). Di dalam Babad Tanah Jawi disebutkan, ada tiga orang Sultan Demak, pertama, Raden Patah atau nama lengkapnya Senopati Ngaddurrahman Panembahan Palembang Sayyidin Panatagama (VBG Deel LI, 1900:78) alias Panembahan Jimbun alias Sultan Bintara, kedua, anaknya, Pangeran Sabrang lor, ketiga, anaknya yang lain lagi, Pangeran Trenggana (Hoesein Djajadiningrat, 1983 :88). Pangeran Sabrang Lor tidak mempunyai keturunan sehingga kedudukannya sebagai raja digantikan oleh adiknya, Pangeran Trenggana. Trenggana mempunyai enam orang anak; yang sulung putri menikah dengan Pangeran Langgar dari Sampang Madura; yang kedua, Pangeran Prawoto; ketiga putri, menikah dengan Pangeran Kalinyamat; keempat, putri menikah dengan Pangeran Cirebon; kelima putri, menikah dengan Raden Jaka Tingkir; yang bungsu putra, bernama Pangeran Timur (Z.H. Sudibyo, 1980: 62-63).

Sejak kematian Sultan Trenggana, Demak di bawah pemerintahan Sunan Prawoto. Sementara itu murid asuhan Sunan Kudus, Pangeran Seda Lepen, saudara kandung Sultan Trenggana yang tidak sempat menjadi sultan, ayah Pangeran Arya Panangsang, ditusuk oleh Sunan Prawoto dengan keris Kyai Betok (VBG. Deel L1, 190:60). Menurut Babad Demak, kemudian Pangeran Arya Panangsang memberontak kepada Pajang, dengan rencana pembunuhan terhadap saudaranya, Sunan Prawoto, pada tahun 1436 (tahun Jawa?, atau tahun Saka) atau sekitar tahun 1514 masehi abad ke-16, adapun menurut catatan BVG. Disebutkan tahun kematian Sunan Prawoto (Sunan Parwata) adalah tahun 1453 A.J. atau tahun 1532 Masehi (J. Brandes, Register op De Proza-Omzeting Van De Babad Tanah Jawi, Dalam BVG. Deel LI, 1900:13).

Satu sisi yang dapat diungkap dari sejarah masa akhir Kerajaan Demak (sejak kematian Sultan Trenggana) ialah, konflik yang terjadi di dalam keluarga kerajaan untuk memperoleh kekuasaan, yang berakibat surutnya Kerajaan Demak. Dibalik konflik tersebut, kemudian muncul kisah tentang orang-orang suci. Pada masa sejarah Islam itulah banyak ditulis naskah historiografi yang dikenal dengan babad, yang didalamnya menceritakan kehidupan para wali yang dianggap sebagi tokoh orang suci, karenanya dikatakan pula sebagai naskah hagiologis. Para wali sangat populer dalam masyarakat Jawa sebagai tokoh Islamisasi di tanah Jawa. Tokoh orang suci menjadi objek utama dalam penulisan, bukan saja pribadi tokoh suci itu yang menjaadi sorotan melainkan juga segala sifat, peralatan, rumah, dan bekas-bekasnya menjadi objek cerita dalam penulisan (Suwedi Montana, 1993/1994:49--50). Sebagia 
besar dari para wali memakai nama sunan, seperti halnya anggota Wali Sanga, Sunan Ampel, Sunan Drajad, Sunan Muria, Sunan Kudus, Sunan Kalijaga, Sunan Gresik, dan Sunan Gunungjati, tidak ketinggalan pula terdapat nama Sunan Prawoto.

Sunan telah menjadi gelar para wali atau pengganti mereka dan ini hanya untuk Giri selama tiga generasi dan rupanya juga untuk Kadilangu selama lima generasi. Kata itu berasal dari bahasa Jawa dan semata-mata berarti "dia yang dihormati" ( Moertono:1985:41). Kasus di Situs Prawata, kemungkinan adalah bagian dari kerangka sejarah masa akhir Kerajaan Demak. Raden Bagus Mukmin, nama asli Sunan Prawoto, setelah membunuh pamannya, Pangeran Sekar, menjadi buta. Dan karena konflik masalah perebutan kekuasaan dalam kerajaan Demak, menyebabkan dirinya lebih memilih pergi dari istana, untuk mendalami agama Islam di Gunung Prawoto.

\section{Fenomena Klasik di Masa Sejarah Islam}

Kebudayaan dapat dipahami sebagai tiga pengertian, wujud kebudayaan sebagai suatu kompleks ide-ide atau gagasan, sebagai kompleks aktivitas manusia, dan sebagai benda-benda hasil karya manusia atau dinamakan pula dengan kebudayaan fisik atau kebudayaan materi. (Koentjaraningrat,1992:5). Kebudayaan materi itulah yang menjadi obyek dari arkeologi untuk mempelajari kehidupan manusia pada masa lampau. Bertolak dari pendapat Koentjaraningrat tersebut diatas maka tinggalan arkeologis berupa artefak memiliki arti penting, karena artefak tidak semata-mata berdiri sendiri sebagai entitas yang mandiri, tetapi berkaitan dengan pola gagasan, ide, yang melatar belakanginya. Dengan demikian ilmu arkeologi yang mempunyai tujuan pengungkapan kembali nila lama dapat diabstraksikan dari tinggalan fisiknya atau kebudayaan materi (Magetsari, 2000:2).

Tinggalan berupa yoni, lapik arca, yang terdapat di Bukit Prawoto, seperti yang telah dijelaskan tersebut di atas, merupakan bukti arkeologis bahwa di sana terdapat tinggalan berunsur budaya Hindu, yang semestinya dihasilkan dan digunakan oleh umat Hindu, untuk kegiatan religius. Bertolak dari tinggalan arkeologis semacam itu semestinya, lokasi tersebut adalah sisa-sisa bangunan sakral. Pendapat semacam itu menjadi bertolak belakang apabila di kaitkan dengan kerangka sejarah, yang berada pada masa Sejarah Islam.

Fenomena klasik-Hindu pada kepurbakalaam di masa sejarah Islam semacam itu, menjadi keunikan ataupun suatu hal yang spesifik. Yoni, dan lapik arca, tetap ada dan digunakan pada bangunan masa Islam, dengan asumsi bahwa benda budaya dari masa Hindu tersebut telah beralih fungsi. Semula berfungsi sakral religius, berubah menjadi 
fungsi konstruktif, misalnya sebagai umpak atau penyangga, atau tiang untuk memperkuat suatu bangunan (profan).

Fenomena klasik-Hindu tidak hanya terlihat dari tinggalan arkeologisnya saja, tetapi terlihat pula pada konsepi pemilihan tempat atau lokasi. Tradisi mendalami agama atau beribadah pada tempat-tempat yang tinggi jauh dari keramaian duniawi, menunjukkan bahwa sejak masa Hindu (bahkan mungkin sejak masa prasejarah) manusia telah memberikan perhatian kepada tempat yang tinggi (perbukitan atau gunung) sehingga manusiapun memberikan perlakuan khusus kepada tempat-tempat semacam itu, misalnya manusia memperlakukan tempat yang tinggi (bukit, gunung) sebagai tempat untuk bertapa, bermeditasi, beribadah, dari pada tempat yang lain sehingga di sana didirikan bangunan suci untuk pemujaan.

Pemilihan gunung (tempat yang tinggi) sebagai tempat keramat memang sudah ada sejak masa klasik atau bahkan masa sebelumnya. Pada masa prasejarah, gunung dianggap keramat karena dipercaya sebagai tempat tinggal arwah nenek moyang, sehingga banyak didirikan bangunan-bangunan pemujaan antara lain berupa menhir dan punden berundak, serta pertapaan-pertapaan di lereng-lereng (ada juga di puncak) gunung. Kepercayaan tersebut tetap berlanjut pada masa Klasik, tetapi peran arwah nenek moyang diganti menjadi dewa-dewa. Sebagai pengganti menhir, punden berundak, dan bangunan pemujaan lainnya serta pertapaan, didirikanlah candi-candi dan wihara. Pusat kegiatan religius masa Hindu dijumpai di Gunung Lawu dan di dataran tinggi Dieng. Disana terdapat Candi Sukuh dan kompleks percandian Dieng.

Rupanya pada masa Islam gunung juga masih tetap mempunyai fungsi dan arti yang penting walaupun konsep yang melatar belakanginya berbeda. Adanya seorang wali yang bernama Sunan Gunungjati juga menunjukkan kalau tokoh yang semula bernama Faletehan atau Fatahillah (ada versi lain yang menyebutkan kalau kedua nama tersebut dimiliki dua tokoh yang berbeda) adalah seorang sunan yang bertempat tinggal di gunung. Pada masa yang lebih kemudian juga ada seorang bupati Semarang yang mengasingkan diri dari kehidupan dunia dan menjadi ulama, juga memilih sebuah bukit di Tembayat, Kabupaten Klaten, sebagai tempat tinggalnya dan akhirnya terkenal dengan sebutan Sunan Bayat (Soewignyo, 1978: 17--19) 


\section{Penutup}

Berdasarkan uraian tentang sejarah dan tinggalan arkeologis di Bukit Prawoto tersebut diatas diketahui, bahwa disana terdápat fenomena klasik-Hindu meskipun berada dalam kerangka sejarah Kerajaan Islam Demak. Fenomena Klasik-Hindu tersebut terlihat pada tinggalan arkeologis dan konsep yang melatarbelakangi pemilihan Bukit atau Gunung Prawoto sebagai tempat untuk mendirikan bangunan pesanggrahan. Yoni, dan lapik arca masih mewarnai konstruksi bangunan pesanggrahan pada masa Kerajaan Demak, tetapi telah dialihkan fungsinya, dari sakral religius menjadi fungsi profan. Adapun konsepsi tentang gunung, merupakan konsep yang telah ada sejak masa klasik-Hindu dan tetap mempunyai arti penting pada jaman Kerajaan Demak.

Situs Prawoto jauh dari asumsi sebagai tempat pemujaan meskipun terdapat tinggalan yoni dan lapik arca. Dilihat dari tinggalan yang ada serta laporan dari Brumund, tentang adanya: gapura, sisa benteng, dan sitinggil, diduga sisa bangunan di situs Dukuh Sewunegaran, Desa Prawoto itu adalah tempat pesanggrahan dari masa Sultan Trenggana, serta tempat menetap ananknya, sunan Prawoto, ketika terjadi konflik di Kerajaan Demak 


\section{KEPUSTAKAAN}

Abdullah, Taufik, dan Abdurrachman Surjomihardjo (Redaktur). 1985. Ilmu Sejarah dan Historiografi. Jakarta: P.T. Gramedia.

Anonim, 1999. Metode Penelitian Arkeologi. Jakarta: Pusat Penelitian Arkeologi Nasional.

Damais, L.C. 1995. Epigrafi dan Sejarah Nusantara, Pilihan Karangan L.C. Damais. Jakarta: EFEO dan Pusat Penelitan Arkeologi Nasional.

Djajadinngrat,Hoesein. 1983. Tinjauan Kritis Tentang Sejarah Banten. Jakarta: Djambatan.

Gina dan Dirgosabariyanto. 1981. Babad Demak 2. Jakarta: Departemen Pendidikan dan Kebudayaan.

Graaf,De. 1985. Awal Kebangkitan Mataram, Masa Pemerintahan Senopati. Jakarta: Grafiti Pers dan KITLV.

Magetsari, Noerhadi. 2000. Nilai Lama Menatap Masa Depan. Makalah disampaikan dalam EHPA di Bedugul, Bali, 14--18 Juli 2000.

Moertono, Soemarsaid. 1985. Negara dan Usaha Bina Negara di Jawa pada Masa lampau. Jakarta: Yayasan Obor Indonesia.

Slamemulyana. 1979. Negarakretagama dan Tafsir Sejarahnya. Jakarta: Bhratara Karya Aksara.

Soewignyo. 1978. Kyai Ageng Pandanarang. Jakarta: Departemen Pendidikan dan Kebudayaan.

Sosrosumarto,K.M. dkk. 1980. Serat Babad Pati. Jakarta: Departemen Pendidikan dan Kebudayaan.

ZH.,Sudibjo. 1980. Babad Tanah Jawi. Jakarta: Departemen Pendidikan dan Kebudayaan.

Laporan Penelitian Arkeologi Bidang Arkeologi Islam Tahun 2000. "Penelitian Pusat-Pusat Permukiman Islam Awal Tahap II di Desa Prawoto, Kabupaten Pati, Jawa Tengah". Jakarta: Pusat Arkeologi. 


\section{VBG. Deel XXXIII Tahun 1868 \\ VBG. Deel XLVII Tahun 1891 \\ VBG. Deel LI Tahun 1900}

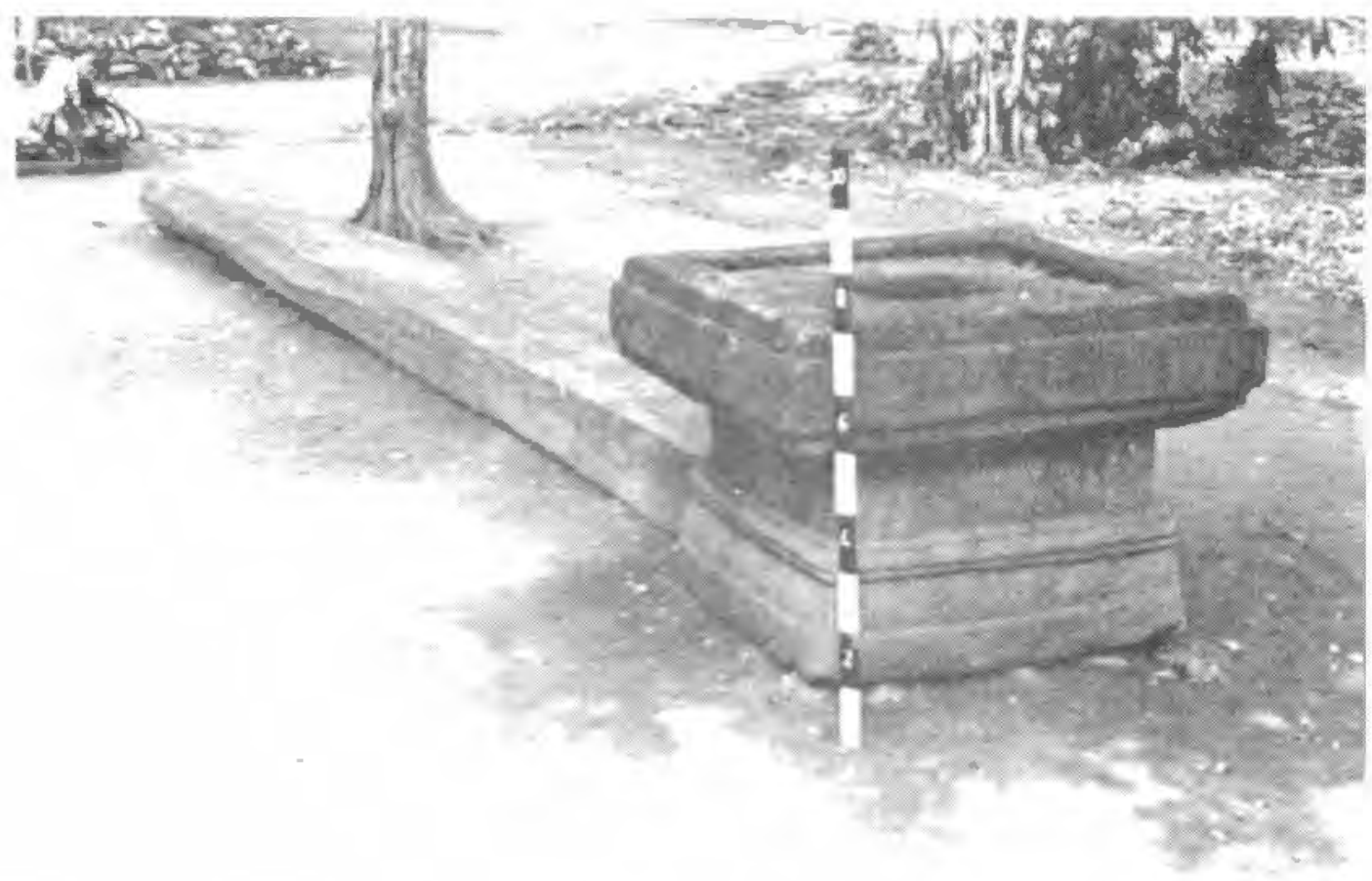

Foto. 1 yoni disebelah Batu Lesung (panjang $\pm 5 \mathrm{~m}$ ), fenomena KlasikHindu tinggalan arkeologi masa Kerajaan Demak di Bukit Prawoto

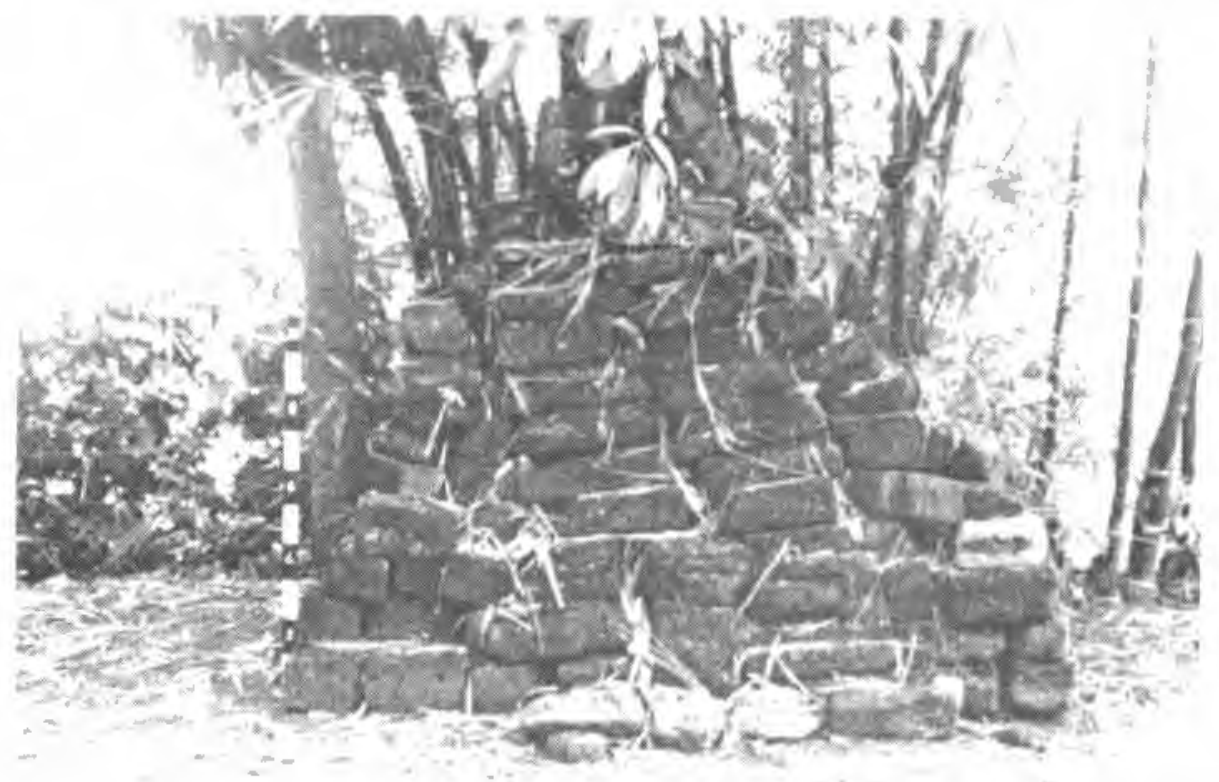

Foto. 2 Tumpukan batu putih, polos dan berpahat \pm 150 meter di sebelah baratlaut "Yoni". Diperkirakan bekas bangunan 


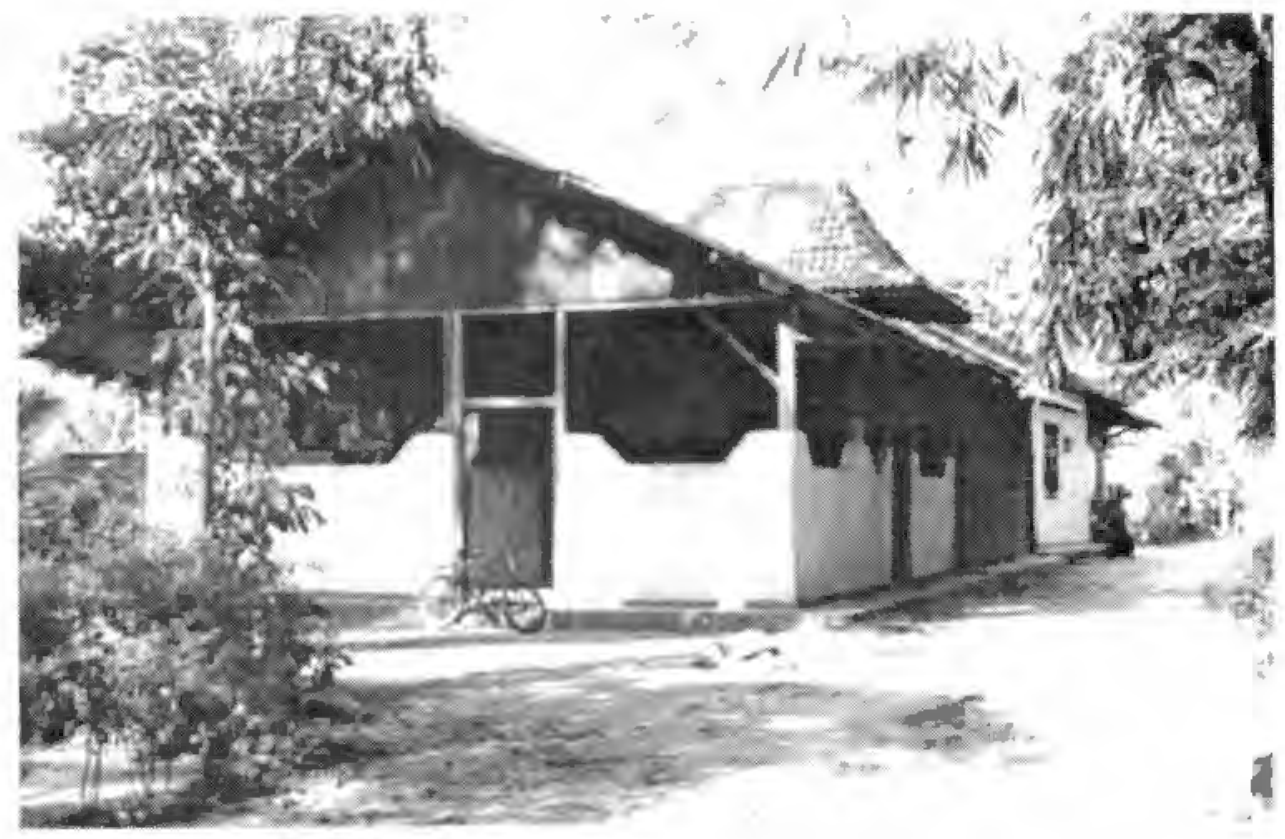

Foto. 3 Cungkup makam (petilasan) Sunan Prawoto, sebelah timur lokasi "Yoni". Hingga sekarang masih banyak dikunjungi peziarah.

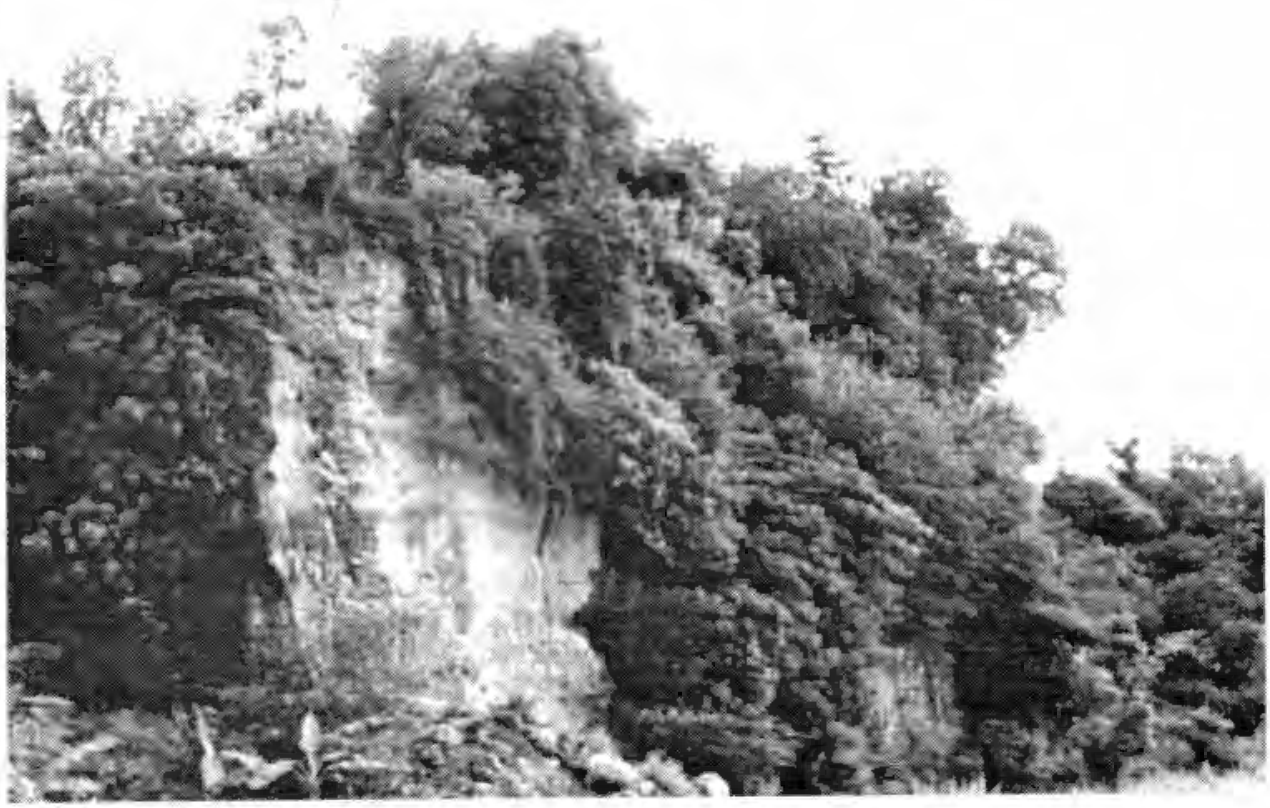

Foto. 4 Bukit Prawoto dilihat dari arah utara. Konsepsi sejak masa Hindu. Sekarang telah dipotong untuk saluran irigasi "Jrantunseluna". Pembangunan yang mengancam kawasan arkeologi. 